\title{
Role of ways of insect visitors foraging for pollination in yield contributing traits of mustard
}

\author{
Md. Iqbal Hossain, ${ }^{1}$ Md. Mizanur Rahman, ${ }^{1}$ Mohammed Sakhawat Hossain, ${ }^{1}$ Rajesh Chakraborty, ${ }^{2}$ \\ Ruhul Amin ${ }^{1}$ \\ ${ }^{1}$ Department of Entomology; ${ }^{2}$ Department of Agronomy, Sher-e-Bangla Agricultural University, Dhaka, Bangladesh
}

\begin{abstract}
The experiment was conducted at the research farm of Sher-eBangla Agricultural University, Dhaka-1207 during the period from November 2016 to February 2017. The experiment consisted of three different ways of insect visitors foraging for pollination of mustard flowers viz., $\mathrm{T}_{1}=$ Open field (Control), i.e., the mustard field was fully open for free movement by the insect pollinators, $\mathrm{T}_{2}=$ Netting with honey bee, i.e., the mustard plots was caged with muslin net and the bee hive was placed inside the cage and $\mathrm{T}_{3}=$ Netting without honey bee, i.e., the mustard plots was caged with muslin net but the bee hive was not placed inside the cage. BARI Sharisha-8 [Brassica juncea (L.) Czernajew] was used as planting material. Randomized Complete Block Design was selected to lay
\end{abstract}

Correspondence: Rajesh Chakraborty, Department of Agronomy, Sher-eBangla Agricultural University, Dhaka-1207, Bangladesh. Tel.: +8801741664970.

E-mail: rajeshmadhobi9@gmail.com

Key words: Mustard; Honeybee; Seed weight; Seed yield; Muslin netting.

Contributions: $\mathrm{MIH}$, data collecting and doing research, MMR and MSH thinking the present research. RA, data collecting. RC manuscript reviewing, writing and references searching.

Conflict of interest: the authors declare no potential conflict of interest.

Funding: the authors are very much grateful to the Ministry of Education of the People's Republic of Bangladesh for the financial support of the study.

Dedication: the authors' would like to dedicate their present piece of research to the farming communities of hunger world.

Received for publication: 6 August 2017.

Revision received: 15 June 2018

Accepted for publication: 21 June 2018.

(C) Copyright Md.I. Hossain et al., 2018

Licensee PAGEPress, Italy

Journal of Biological Research 2018; 91:6982

doi:10.4081/jbr.2018.6982

This article is distributed under the terms of the Creative Commons Attribution Noncommercial License (by-nc 4.0) which permits any noncommercial use, distribution, and reproduction in any medium, provided the original author(s) and source are credited. out the present experiment with 7 replicates. Study showed that honey bee was the most abundant hymenopterans in the mustard field as a pollinator. The yield and yield contributing traits were significantly influenced by different ways of insect visitors foraging for pollination. The maximum (3.50 g) 1000-seed weight was recorded from treatment $T_{2}$ followed by $T_{3}$ and the lowest 1000seed weight $(2.68 \mathrm{~g})$ was recorded from $\mathrm{T}_{3}$. The highest seed yield $\left(2.45 \mathrm{t} \mathrm{ha}^{-1}\right)$ was exhibited from treatment $\mathrm{T}_{2}$ followed by $\mathrm{T}_{1}$ whereas the lowest seed yield $\left(1.67 \mathrm{tha}^{-1}\right)$ was recorded from $\mathrm{T}_{3}$. Finally, it can be concluded that providing honey bee colonies to the flowering mustard field can substantially contribute to the yield.

\section{Introduction}

Mustard; Brassica juncea (L.) Czernajew, tori sharisha and Brassica napus (L.), rye sharisha are the most cultivated species in Bangladesh. They ranked second most important edible oilseed crops of the world after soybean and the oldest cultivated amphidiploids $^{1}$ which are a dicotyledonous angiosperm plant belongs to Brassicaceae or Cruciferaceae family. ${ }^{2,3}$ Edible oil plays a very important role in human nutrition. As a high-energy component of food, edible oils are important for meeting the calorie requirements. Fats and oils are also the sources of essential fatty acids. The main essential fatty acids of vegetable oils are linoleic and linolenic acids. Fats and oils are used to synthesize phospholipid, which are important components of active tissues viz., brain, nerve, and liver of human beings and other animals. These crops are grown under a wide range of agro-climatic conditions. Indian mustard is the most important member of this group, accounting for more than $70 \%$ of the area under rapeseed-mustard, followed by toria, yellow sarson and brown sarson. ${ }^{2,3}$ The oil content varies from 37 to $49 \%$ in Brassica juncea (Indian mustard). ${ }^{4}$ Rapeseed-Mustard is a principal oilseed crop, which plays a significant role in the national economy of Bangladesh. But seed yield/ha is very low compared to other mustard (tori/rye) growing countries of the world because the productivity of this crop is very low. The area for mustard production in Bangladesh has been on increase but the productivity has been diminishing hence the indigenous oil production of the state could not match the growing demand of population. ${ }^{5}$

The low average yield of mustard is due to cultivation of traditional varieties, non-availability of seeds of high yielding varieties and delayed sowing. ${ }^{5}$ Although such decline could be attributed to pests, diseases damage, poor soil fertility or water stress, there is evidence that insufficient pollination can also significantly minimize the crop yield. ${ }^{6}$ According to Sushil et al., ${ }^{7}$ low seed yield due to inadequate pollination is often faced as a major problem of Brassica seed production. Inadequate pollination is caused by sev- 
eral factors and the most important of which include the lack of adequate number and diversity of pollinators. Thus, there is a need to ensure pollination by conserving the pollinators and attracting them towards the crop land. Pollination by insects is inevitable for Brassica, since they are generally incompatible (does not take part in fertilization process by pollen rain with ovule) in self pollination ${ }^{8}$ and the pollen is heavier and sticky, which is unable to be easily wind-borne. The blooming phase of any plant is the most crucial stage as the diversity of insects is higher than any other phase of plant species. ${ }^{9,10}$ Besides contributing to the preservation of natural ecosystems, bee pollination is one of the main alternatives for the improvement of crop productivity. ${ }^{11,12}$ Thus, honey bees, Apis mellifera $\mathrm{L}$. are considered the most important flower visitors ${ }^{13}$ of most efficient B. napus L. ${ }^{6,14}$ However, the role of hymenopterans insect, especially honey bee on the productivity of mustard through cross pollination as an insect vectors is not well investigated to the researchers'. So, keeping the fact in view the present study was undertaken to study the effect of the managed bee on the yield and yield contributing characters of mustard.

\section{Materials and Methods}

\section{Site description of research areas}

Research farm of Sher-e-Bangla Agricultural University, Dhaka-1207 was used to conduct the present study during the period from November 2016 to February, 2017 which covered the full growing period of mustard in Bangladesh. The experimental field was located at $90^{\circ} 33 \mathrm{E}$ longitude and $23^{\circ} 71 \mathrm{~N}$ latitude at a height of $8 \mathrm{~m}$ above the sea level. The land of the research area was medium high in topography. The $\mathrm{pH}$ of the research plot was 5.57 and soil texture was silty clay in nature which contained $24 \%$ sand, $48 \%$ silt, and $28 \%$ clay. This value seemed the general observation of experimental area for normal growth of mustard plant but the analysis was not done based on the emphasis for seeing the variation of experimental plots. The physico-chemical properties of the soil are presented in Table 1. The research area belonged to the Madhupur Tract Agro-Ecological Zone (AEZ-28). Sub-tropical climate is characterized by the research areas with three distinct seasons, kharif-1 (April-June), kharif-2 (July-September) and robi/winter (October-March). This weather is favorable for crop production due to lower rainfall found during this period and it did not hampered the crop cycle. The average maximum temperature during the period of the experiment was $29.19^{\circ} \mathrm{C}$ and the average minimum temperature was $9.16^{\circ} \mathrm{C}$.

Details of the meteorological data related to the temperature, relative humidity, and rainfalls during the period of the experiment were collected from the Bangladesh Meteorological Department, Dhaka and presented in Table 2.

\section{Experimental details}

\section{Crop}

BARI Sharisha-8 (Brassica juncea L.) was used as planting material. It is herbaceous growing to a height of 0.9 to 1.10 meters with tap root system and it has the potentiality to give 2.0-2.5 tons seed per hectare at well-managed condition. ${ }^{15}$

\section{Experimental design and treatments}

Randomized Complete Block Design (RCBD) was selected to lay out the present experiment. The unit plot size was $2.5 \mathrm{~m} \times 2.0$ $\mathrm{m}$. Seven replicates were taken having $1.0 \mathrm{~m}$ space between the replicates and $0.75 \mathrm{~m}$ between the plots. Each plot contained two rows having $40 \mathrm{~cm}$ distance between the row and that between plants was $10 \mathrm{~cm}$. The experiment consisted on three treatments such as, $\mathrm{T}_{1}=$ Open field (Control), i.e., the mustard field was fully open for free movement by the insect pollinators, $\mathrm{T}_{2}=$ Netting with honey bee, i.e., the mustard plots was caged with muslin net and the bee hive was placed inside the cage and $T_{3}=$ Netting without honey bee, i.e., the mustard plots was caged with muslin net but the bee hive was not placed inside the cage. Each treatment was randomly placed in each replicate. Two frame nucleus boxes having 200 individuals were used as raring for honey bees and sugar candy binding with a stick was placed in cage as supplemental food for the honey bee (Figure 1).

\section{Crop husbandry}

A power tiller was used to open the plots selected for the research in the last week of October 2016 and exposed to the sun for a week, after which the land was harrowed, ploughed and cross-ploughed four times followed by laddering to obtain a good tilt condition of soil with the removal of weeds and stubbles. After collecting the seeds were treated with Provex 200 WP @2 g per

Table 1. The physicochemical properties of the soil of research plot (0-15 cm depth).

\begin{tabular}{lc} 
Soil parameters & Observed values \\
$\mathrm{pH}$ & 5.57 \\
Total N (\%) & 0.0679 \\
\hline Phosphorus & $21.25 \mu \mathrm{g} / \mathrm{g}$ soil \\
Sulphur & $24.29 \mu \mathrm{g} / \mathrm{g}$ soil \\
\hline Boron & $0.52 \mu \mathrm{g} / \mathrm{g}$ soil \\
Copper & $3.38 \mu \mathrm{g} / \mathrm{g}$ soil \\
\hline Zinc & $2.98 \mu \mathrm{g} / \mathrm{g}$ soil \\
\hline
\end{tabular}

Source: Soil Resources Development Institute (SRDI), Khamarbari, Dhaka.

Table 2. Monthly meteorological information during the period from November 2016 to February 2017.

\begin{tabular}{|c|c|c|c|c|c|}
\hline \multirow[t]{2}{*}{ Year } & \multirow[t]{2}{*}{ Month } & \multicolumn{2}{|c|}{ Air temperature $\left({ }^{\circ} \mathrm{C}\right)$} & \multirow[t]{2}{*}{ Relative humidity (\%) } & \multirow[t]{2}{*}{ Total rainfall (mm) } \\
\hline & & Maximum & Minimum & & \\
\hline \multirow[t]{4}{*}{ 2016-2017 } & November & 29.19 & 12.23 & 57.28 & 49 \\
\hline & December & 26.00 & 9.16 & 70.43 & 1 \\
\hline & January & 24.92 & 9.87 & 72.79 & Trace \\
\hline & February & 25.85 & 14.54 & 78.42 & Trace \\
\hline
\end{tabular}

Source: Metrological Centre (Climate Division), Agargaon, Dhaka. 
$\mathrm{kg}$ seed to protect seedlings against foot and root rot diseases and from later Alternaria blight. During land preparation, $8 \mathrm{t} / \mathrm{ha}$ decomposed cow dung was mixed. Urea, TSP, MoP, Gypsum, Zinc sulphate and Boric acid were applied as the source of Nitrogen $(\mathrm{N})$, Phosphorus $\left(\mathrm{P}_{2} \mathrm{O}_{5}\right)$, Potassium $\left(\mathrm{K}_{2} \mathrm{O}\right), \mathrm{S}, \mathrm{Zn}$ and Boron $(\mathrm{B})$ at the rate of $250,180,100,150,7$ and $10 \mathrm{~kg}$ per hectare. At November 7,2016 , seeds are sown continuously in $2-2.5 \mathrm{~cm}$ deep furrows made by hand iron tine maintaining desired row spacing. Before seed placement in rows light water was applied in furrows for the easy emergence of seeds. After placement of seeds were covered with soil by hand. Within ten days of sowing the germination was satisfactory. Operations like thinning, weeding, watering and drainage and pest Management were done as and when necessary for proper growth and development of the crop.

\section{Parameters taken}

\section{Overall parameters studied}

At physiological maturity stage, the crop was harvested. Data on, plant height $(\mathrm{cm})$, number of primary branches plant $^{-1}$, pod formation at 45, 55 and 65 DAS (Days after sowing), number of siliqua plant $^{-1}$, number of seeds siliqua ${ }^{-1}, 1000$-seed weight $(\mathrm{g})$, seed yield $\left(\mathrm{t} \mathrm{ha}^{-1}\right)$.

Finally, overall increases of seed yield over control were seen, and the correlation coefficient was calculated by using Excel spreadsheet among the number of siliqua plant $^{-1}$, number of seeds siliqua $^{-1}$ and seed yield were calculated to show the importance of honey bee pollination of mustard flowers.

\section{Counting the visiting insects order}

Hymenopterans pollinator and other foraging insects were counted on this cultivar by seeing up on the net and open plots at morning and afternoon throughout the blooming period and counting the number of hymenopterans pollinator and other foraging insects actively collecting nectar or pollen. The visiting insects were identified on the basis of internet browsing and also by using the knowledge available in research expertise of Bangladesh locally under mustard research.

Flower visitors, along with the number of flowers visited and the total number of flowers per patch were recorded. This allowed calculation of abundances and visitation rates for different species groups, calculated as the proportion of flowers visited per species in a 5 min period during both morning and afternoon (where that species was present).

\section{Statistics}

After collection of all the data, those were analyzed following the ANOVA techniques by using the Web Agri Stat PackageWASP (Version-1) computer package program. The means were separated by using Least Significant Difference (LSD) at 5\% level of probability. Graphs and figures were created by using MS Excel spreadsheet. Correlation line was created by using MS Excel spreadsheet, also.

\section{Results and Discussion}

\section{Diversity of visiting insect}

Different insects visited experimental plots during experimentation period (Figure 2A). Among different insects, the hymenopterans dominated the mustard field followed by lepidopterans, coleopterans, dipterans insect and lowest insect visitors were homopterans (1\%). Mahfouz et al. ${ }^{16}$ found the similar pattern of insects foraging for pollination of sesame and they found that, hymenopterans were the most forgeable insects order in rapeseed plant. Stanley et al. ${ }^{17}$ stated that the pollinators can differ in terms of their efficiency of crop pollination. They also found that the honeybee, Eristalis hoverflies and bumblebees were the most useful pollinators of winter oilseed rape based on the amount of pollen carried, visitation rates and their abundance. Rader et al. ${ }^{18}$ reported that honey bees are not the only insects that pollinate crops. Apart from a few managed bee taxa, the great majority of other pollinators are free-living or wild, providing an ecosystem service to crops. Wild pollinators other than honey bees recently have been recognized for their role in increasing and stabilizing crop-pollination services. Increasingly, studies indicated that insect pollinators other than bees, such as flies, beetles, moths, and butterflies, are equally if not more important for the production of some crops. ${ }^{18}$

\section{Plant height}

The plant height of mustard was not significantly ( $p>0.05$, df: 2 , sd: 0.87 ) differed due to different pollination condition (Figure 2B). Numerically the tallest plant $(96.80 \mathrm{~cm})$ was recorded from netting with honey bee $\left(\mathrm{T}_{2}\right)$ and the shortest plant $(94.85 \mathrm{~cm})$ was recorded from netting without honey bee $\left(\mathrm{T}_{3}\right)$. The honey bee has no any effects on plant height due to it is a varietal trait. So, under present study, no significant differences among pollination modes were found.

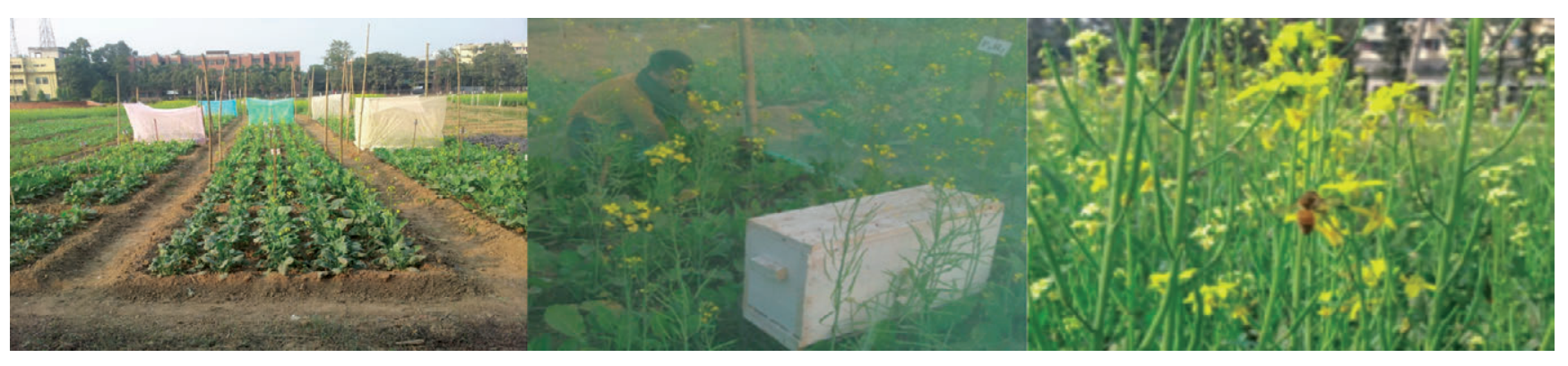

Figure 1. Experimental overviews. 


\section{Number of primary branches plant ${ }^{-1}$ (no.)}

Here we have simply noticed the differences found under different plots due to their normal growth and varietal potentiality. The number of primary branches plant ${ }^{-1}$ of mustard varied under different pollination condition (Figure 3A). The results of the experiment revealed that the maximum number of primary branches plant ${ }^{-1}$ was recorded when the plots netting with honey bee $\left(\mathrm{T}_{2}\right)$ followed by $T_{1}$ and the minimum number of primary branches plant $^{-1}$ was recorded from when the plots netting without honey bee $\left(\mathrm{T}_{3}\right)$.

\section{Number of siliquae setting plant ${ }^{-1}$ (no.)}

The number of siliquae setting plant $^{-1}$ of mustard was significant due to different pollination condition at 45, 55 and 65 DAS (Table 3). The maximum number of siliquae setting plant ${ }^{-1}$ (124.30, 133.30, 137.00 at 45, 55 and 65 DAS, respectively) were recorded from treatment $T_{2}$ followed by $T_{1}$ at 45,55 and 65 DAS and the minimum number of siliquae setting plant ${ }^{-1}(92.25,98.25$ and 100.83 at 45, 55 and 65 DAS, respectively) was produced by $\mathrm{T}_{3}$ treatment. Kumar et al. ${ }^{19}$ found that the seed set was highest $(75.5 \%)$ with hand + insect pollination than open pollination and

Table 3. Effect of different pollination condition on the number of siliquae setting plant $^{-1}$ of mustard at different days after sowing.

\begin{tabular}{|c|c|c|c|}
\hline Treatments & $\begin{array}{c}\text { No. of : } \\
45\end{array}$ & $\begin{array}{l}\text { at diffe } \\
55\end{array}$ & $\begin{array}{c}\text { (DAS) } \\
65\end{array}$ \\
\hline $\mathrm{T}_{1}$ & $108.5 \mathrm{~b}$ & $115.57 \mathrm{~b}$ & $119.0 \mathrm{~b}$ \\
\hline $\mathrm{T}_{2}$ & $124.3 \mathrm{a}$ & $133.3 \mathrm{a}$ & 137.0 a \\
\hline $\mathrm{T}_{3}$ & $92.25 \mathrm{c}$ & $98.25 \mathrm{c}$ & $100.83 \mathrm{c}$ \\
\hline $\operatorname{LSD}_{(0.05)}$ & 14.32 & 16.33 & 17.41 \\
\hline
\end{tabular}

$\mathrm{T}_{1}=$ Open field (Control), $\mathrm{T}_{2}=$ Netting with honey bee, $\mathrm{T}_{3}=$ Netting without honey bee.

A

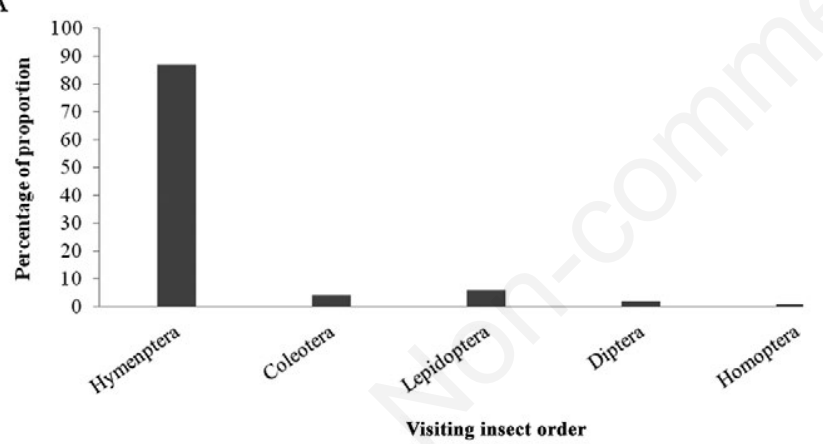

B

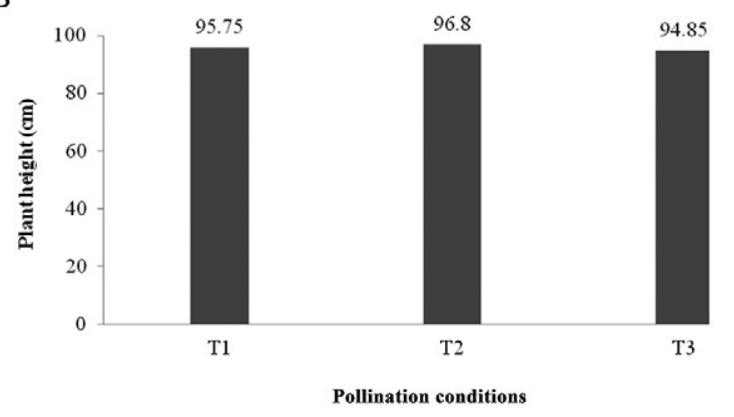

Figure 2. (A) Percentage of the major insect orders visited in mustard field during the flowering period; (B) Effect of different pollination condition on the plant height of mustard $(\operatorname{LSD}(0.05)=N S)$. $T 1=$ Open field (Control), T2=Netting with honey bee and T3=Netting without honey bee.

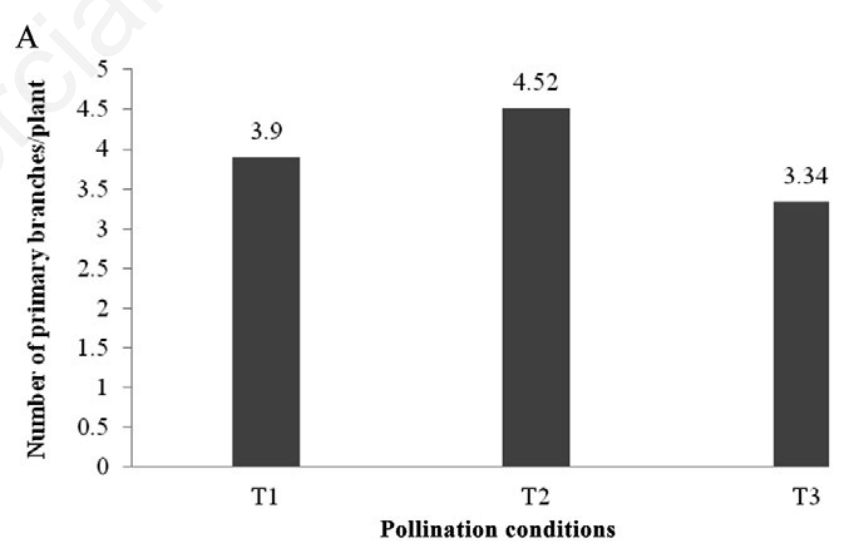

B

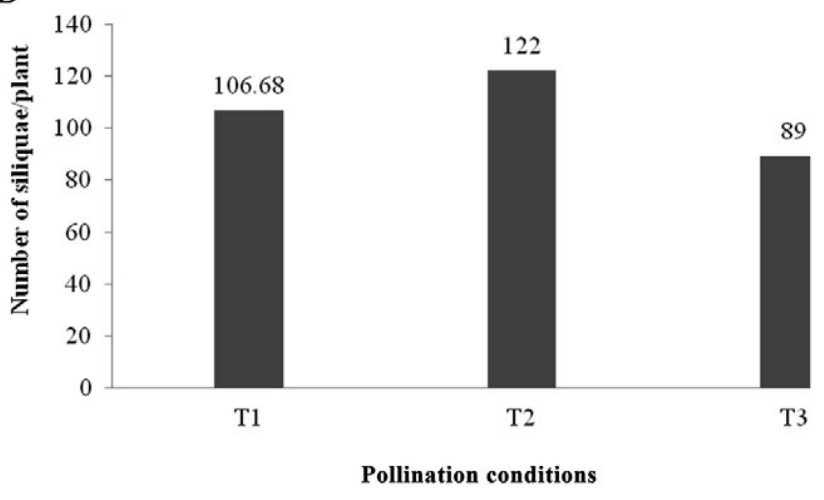

Figure 3. (A) Effect of different pollination condition on the number of primary branches plant ${ }^{-1}$ of mustard (LSD (0.05) $\left.=0.54\right)$; (B) Effect of different pollination condition on the number of siliquae plant $^{-1}$ of mustard $(\mathrm{LSD}(0.05)=15.15)$. T1=Open field (Control), T2=Netting with honey bee and T3=Netting without honey bee. 
the crop netted without bees in sunflowers. Varma et al..$^{20}$ also compared the honey bee pollination with other insects' pollination on mustard bloom and they found that the honey bee pollination increased the pod set by 74.3 per cent.

\section{Number of siliquae plant ${ }^{-1}$ (no.)}

The number of siliquae plant ${ }^{-1}$ of mustard varied significantly due to different pollination condition (Figure 3B). The result revealed that the highest number of siliquae plant ${ }^{-1}$ (122.00) was found from treatment $T_{2}$ followed by $T_{1}$ and the lowest number of siliquae plant ${ }^{-1}$ (89.00) was found from $\mathrm{T}_{3}$. Atmowidi et al. ${ }^{21}$ reported that the number of pods increased by three times in insect pollinated plots of mustard (B. rapa). Kumar et al. ${ }^{19}$ also found that the number of filled seeds per capitulum (728.2) was highest with hand + insect pollination than open pollination and the crop netted without bees in sunflowers.

\section{Number of seeds siliqua ${ }^{-1}$}

The number of seeds siliqua ${ }^{-1}$ of mustard significantly varied due to different pollination condition (Figure 4A). The result revealed that the highest number of seeds siliqua ${ }^{-1}$ (28.50) was recorded from treatment $T_{2}$ and the lowest number of seeds siliqua ${ }^{-1}$ (15.75) was recorded from $T_{3}$. The present findings were in agreement with Kumar et al. ${ }^{19}$ who observed that B. juncea plants caged with bees produced 25 percent more seed than plants caged without bees. Munawar et al. ${ }^{22}$ found that the number of filled seeds per capitulum was highest with hand + insect pollination than open pollination and the crop netted without bees in sunflowers Kumar

A
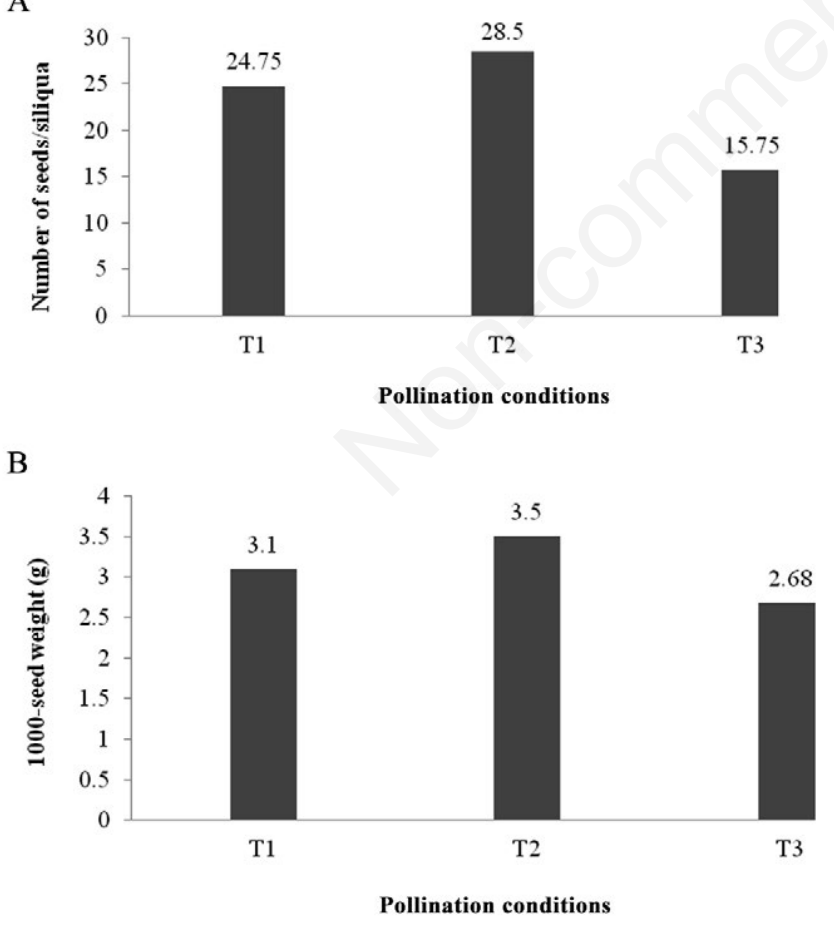

Figure 4. (A) Effect of different pollination condition on the number of seeds siliqua ${ }^{-1}$ of mustard $(\operatorname{LSD}(0.05)=2.31)$. T1 $=$ Open field (Control), T2=Netting with honey bee and T3=Netting without honey bee; (B) Effect of different pollination condition on the 1000 -seed weight of mustard $(\operatorname{LSD}(0.05)=0.35)$. T1 $=$ Open field (Control), T2=Netting with honey bee and T3=Netting without honey bee. et al. ${ }^{19}$ reported that number of seeds per pod increased $98.2 \%$ in insect pollinated plots of mustard (B. rapa).

\section{0-seed weight (g)}

Different pollination condition significantly affected the 1000seed weight of mustard (Figure 4B). The highest 1000-seed weight $(3.50 \mathrm{~g})$ was recorded from treatment $\mathrm{T}_{2}$ followed by $\mathrm{T}_{1}$ and the lowest 1000 -seed weight $(2.68 \mathrm{~g})$ was recorded from $\mathrm{T}_{3}$. The present result is in partial agreement with Atmowidi et al. ${ }^{21}$ who reported that the test weight of 1000-seed of canola, Brassica napus was with highest seed weight plants caged with honeybees $(26.00 \mathrm{~g})$. The lowest was in plants caged without honeybees $(9.30 \mathrm{~g})$. Latif et $a l .{ }^{23}$ reported that seed produced in cages with honey bees was heavier than the seeds from open plots of $B$. juncea. Singh et al. ${ }^{24}$ reported that bee pollinated plots produced three times heavier seeds than self-pollinated plants in $B$. campestris var. toria.

\section{Seed yield $\left(\mathrm{t} \mathrm{ha}^{-1}\right)$}

Seed yield of mustard significantly influenced by different pollination condition (Figure 5). The highest seed yield $\left(2.45 \mathrm{t} \mathrm{ha}^{-1}\right)$ was recorded from treatment $T_{2}$ followed by $T_{1}$ and the lowest seed yield $\left(1.67 \mathrm{t} \mathrm{ha}^{-1}\right)$ was recorded from $\mathrm{T}_{3}$. Kumar et al. ${ }^{19}$ who also recorded the higher seed yield of sunflower $(849 \mathrm{~kg} / \mathrm{ha})$ in the intercropping system of sunflower + niger and lowest was in a sole crop of sunflower $(747 \mathrm{~kg} / \mathrm{ha})$ indicating the role of pollinators in both cross-pollinated crops. The main reason for the higher seed yield per hectare may be the higher weight of seed per plant and higher 1000-seed weight may also be the reasons for highest seed yield. Singh et al. ${ }^{24}$ emphasized upon the view that insect pollination led to the formation of well-shaped larger grains and more viable seeds than self-pollinated plants. Sanas et al. ${ }^{25}$ who also reported that increased production of sunflower seed in an area with the introduction of honey bees related to areas without bees. Netting with honeybee $\left(\mathrm{T}_{2}\right)$ produced $(6.52 \%)$ higher seed yield over control $\left(\mathrm{T}_{1}\right)$ and $\mathrm{T}_{3}$ exhibited the negative response $(-27.39 \%)$ on seed yield increase over control. Singh et al. ${ }^{26}$ reported that, the honey bee introduced plots of cauliflowers gave the increasing percent of seed yield than that of open pollinated plots.

\section{Correlation coefficient (r)}

Data from harvested plant samples were used to calculate the correlation coefficient (r). Here we tried to show only the apparent normal relationship among these traits of mustard plant. Different

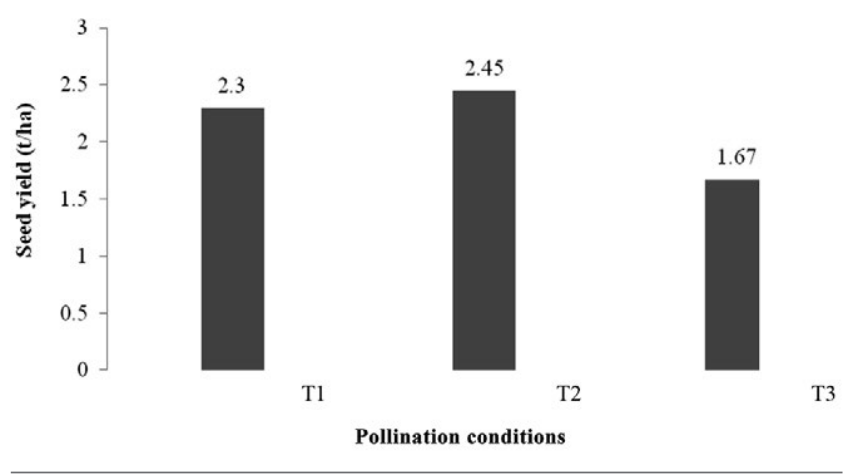

Figure 5. Effect of different pollination condition on the seed yield of mustard $(\operatorname{LSD}(0.05)=0.14)$. T1 $=$ Open field (Control), T2=Netting with honey bee and T3=Netting without honey bee. 
A

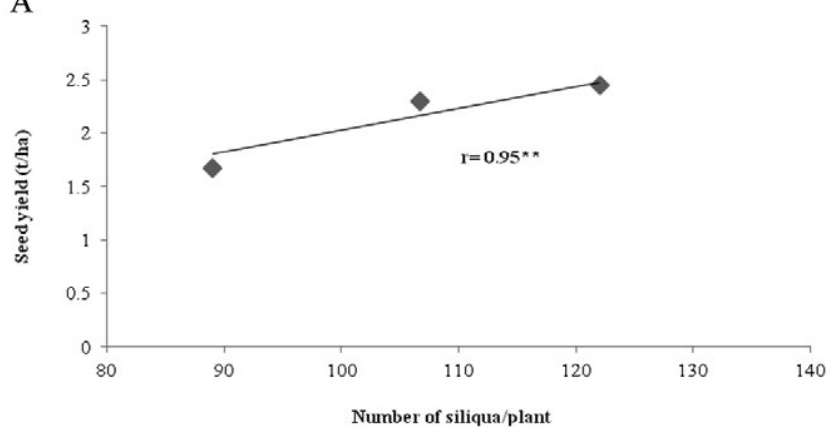

B

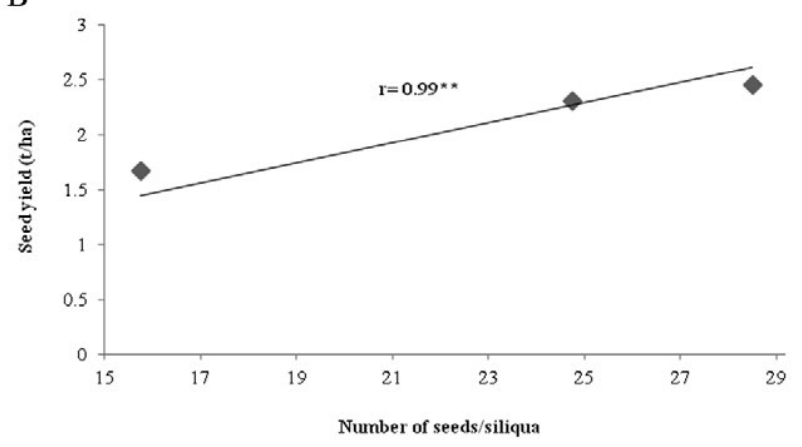

Figure 6. (A) The relationship between number of siliquae plant ${ }^{-1}$ and seed yield $\left(\mathrm{t} \mathrm{ha}^{-1}\right)$ of mustard; (B) Relationship between number of seeds siliqua ${ }^{-1}$ and seed yield $\left(\mathrm{tha}^{-1}\right)$ of mustard.

pollination conditions influenced the different traits of mustard and so, the correlation coefficient was calculated among some yield and yield contributing traits. A linear relation $(r=0.95)$ was exhibited between the number of siliquae plant ${ }^{-1}$ and seed yield $\left(\mathrm{t} \mathrm{ha}^{-1}\right)$ of mustard (Figure 6A).

In Figure 6B, a linear relation $(\mathrm{r}=0.99)$ was found between number of seeds siliqua ${ }^{-1}$ and seed yield $\left(\mathrm{t} \mathrm{ha}^{-1}\right)$ of mustard. From the correlation study it may be said that, there was about 95 to $99 \%$ of seed yield of mustard was dependent on different yield contributing traits. Correlation among various characters indicated that all these characters had significant contribution to seed yield and yield would be increased by improving these yield attributes.

\section{Conclusions}

Based on the results of the present study the following conclusion could be drawn that, the honey bee is the most abundant hymenopterans in the mustard field as a pollinator. The growth, yield and yield contributing traits were significantly influenced by different strategies of pollination by the honey bee. Netting with honey bee was the best one for better yield of mustard.

\section{References}

1. Hemingway JS. Mustards Brassica species and Sinapis alba (Cruciferae). In: Simmonds NW, ed. Evolution of Crop Plants. London and New York: Longman; 1976. pp 56-59.
2. Bhowmik B, Mitra B, Bhadra K. Diversity of insect pollinators and their effect on the crop yield of Brassica juncea L., NPJ93, from southern West Bengal. Intl J Rec Sci Res 2014;5:1207-13.

3. Ahlabat IPS. Agronomy-Rabi crops, Rapeseed and mustard, Division of Agronomy. New Delhi: Indian council of Agricultural Research; 2010.

4. Jaga PK. Comparative response to sulphur application in mustard (Brassica juncea L.) and wheat (Triticum aestivum). Innovare J Agril Sci 2013;1:4-6.

5. Alam MM, Begum F, Roy P. Yield and yield attributes of rapeseed-mustard (Brassica) genotypes grown under late sown condition. Bangladesh J Agril Res 2014;39:311-36.

6. Free JB. Pollination in the tropics. Beekeeping Deve 1999;51:6-7.

7. Sushil SN, Stanley J, Hedau NK, Bhatt JC. Enhancing seed production of three Brassica vegetables by honey bee pollination in north-western Himalayas of India. Univ J Agril Res 2013;1:49-3.

8. Sihag RC. Why should bee-keeping be utilized as an input in agriculture? Curr Sci 2001;81:1514-6.

9. Bhalchandra W, Baviskar RK, Nikam TB. Diversity of nectariferous and polleniferous bee flora at Anjaneri and Dugarwadi hills of Western Ghats of Nasik district (M. S.) India J Entomol Zool Stud 2014;2:244-9.

10. Rasheed MT, Inayatullah M, Shah B, et al. Identification and record of insect pollinators on two cultivars of sunflower. J Entomol Zool Stud 2015;3:178-9.

11. Westcott L, Nelson D. Canola pollination: an update. Bee World 2001;82:115-29.

12. D'Avila M, Marchini LC. Pollination provided by bees in economically important crops in Brazil. Boletim da Industria Animal 2005;62:79-80.

13. Delaplane KS, Mayer DR, Mayer DF. Crop pollination by bees. Cabi 2000;352.

14. Sabbahi R, Oliveirara D, Marceau J. Influence of honey bee (Hymenoptera: Apidae) density on the production of canola (Cruciferae: Brassicaceae). J Econ Entomol 2005;98:367-72.

15. BARI. Bari udbhabito fosoler jat somuho. Annual Report 2017;24.

16. Mahfouz H, Kamel S, Belal A, Said M. Pollinators visiting sesame (Sesamum indicum L.) seed crop with reference to foraging activity of some bee species. Cercetari Agronomice in Moldova 2012;45:49-5.

17. Stanley DA, Gunning D, Stout JC. Pollinators and pollination of oilseed rape crops (Brassica napus L.) in Ireland: ecological and economic incentives for pollinator conservation. J Insect Conserv 2013;17:1181-9.

18. Rader R, Bartomeus I, Garibaldi LA, et al. Non-bee insects are important contributors to global crop pollination. Proceedings of the National Academy of Sciences 2016;113:146-51.

19. Kumar M, Singh R. Pollination efficiency of Apis mellifera in seed production of sunflower, Helianthus annuus L. J Entomol Res 2003;27:131-4.

20. Varma SK, Joshi NK. Studies on the role of honey bees in the pollination of Cauliflower (Brassica oleracea var. botryis). Indian Bee J 1983;45:45-55.

21. Atmowidi T, Buchori D, Manuwoto S, et al. Diversity of pollinator insects in relation to seed set of mustard (Brassica rapa L.: Cruciferae). Hayati J Biosci 2007;14:155-61.

22. Munawar MS, Raja S, Siddique M, et al. The pollination by honeybee (Apis mellifera L.) increases the yield of canola (Brassica napus L.). Pakistan Entomol 2009;31:103-6. 
23. Latif A, Qayyrem A, Abbas M. The role of Apis indica in the pollination of toria and sarson (Brassica campestris var. toria and dichotoma). Bee World 1960;41:283-6.

24. Singh RP, Singh PN. Impact of bee pollination on seed yield, carbohydrate composition and lipid composition of mustard seed. J Apicul Res 1992;31:128-33.

25. Sanas AP, Narangalkar AL, Godase SK, Dalvi VV. Effect of honeybee pollination on quantitative yield parameters of mustard (B. juncea) under Konkan condition of Maharastra. Green Farm 2014; 5: 241-243.

26. Singh P, Singh KM, Shahi B. Role of Honey Bee Pollination in Quality Seed Production of Cauliflower for Scalingup of Livelihood in Vaishali District of Bihar. J AgriSearch 2016;3:115-8. 